\title{
Biochemical Bone Indices and Serum Uric Acid Changes in Postmenopausal Women
}

\author{
Rukzan M. Dawood \\ Department of Chemistry \\ College of Education for Girls \\ University of Mosul
}

(Received 13/9/2012; Accepted 17/12/2012)

\begin{abstract}
The objective of this study was to evaluate the effect of menopause on: body mass index (BMI), serum levels of total protein, albumin, globulin, total calcium, uric acid, activity of acid phosphatase (ACP) and tartarate-resistant acid phosphatase (TRACP 5b). The study involves 50 participants who were categorized into two groups; premenopausal women group $(\mathrm{n}=25)$ (age, $47.18 \pm 4.10$ years) and postmenopausal women group $(\mathrm{n}=25)$ (age, $58.58 \pm 4.51$ years). In comparative evaluation, the serum total protein, calcium, uric acid, activity of ACP and TRACP $5 b$ were found to be significantly increased $(p<0.05)$ in post menopausal women as compared to premenopausal women. Postmenopausal women are exposed to a greater risk of serum biochemical changes as compared to the premenopausal women, thus leading to an increased risk of osteoporosis and cardiovascular diseases after menopause.
\end{abstract}

Keywords: Postmenopausal women, osteoporosis, tartarate resistant acid phosphatase, total and ionized calcium.

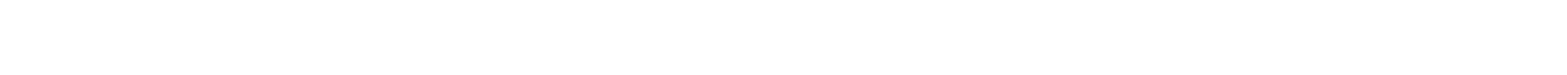 لالمث}

\section{الماضغص}

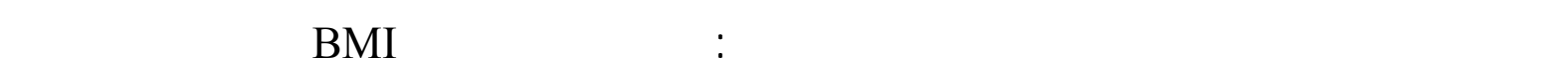
البروتين الكلي، الألبومين، الكلوبيولين، الكللسيو، حلمض البوليك، فعالية أنزيم الفوسفاتيز الحلمضي (ACP)

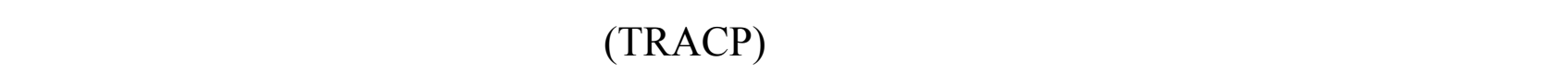

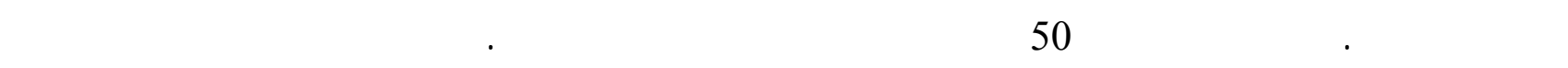

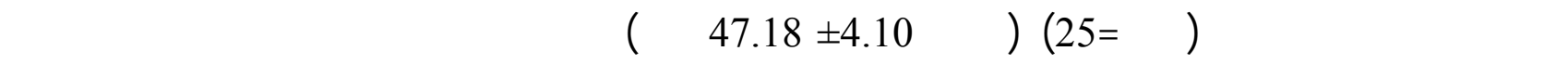
التطاع الطمث (العدد 25) (العمر 51 .4 (p<0.05) في كل من مستوى البروتين الكلي، الكللسيو،، حلمض البوليك، فعالية كل من أنزيم الفوسفاتيز 
الحلمضي و الفوسفاتيز الحلمضي المقاوم للترترات 5b في مجموعة النساء بعدسن انتطاع الطمث بالمقارنة

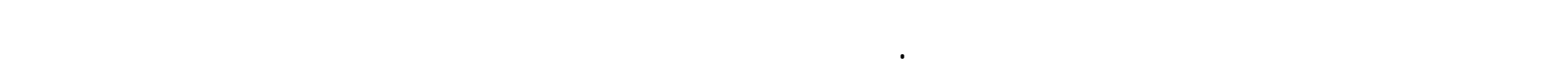

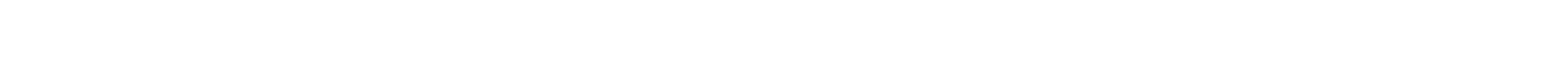
الوعائية.

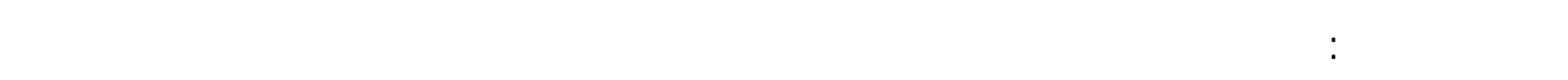 للترترات، الكللسيوم الكلي والمتأين.}

\section{INTRODUCTION}

Menopause is defined as the cessation of menstruation for a period of longer than one year. It begins with changes in ovarian function and gradual decrease in the production of estrogen and other hormones (Padubidri et al., 2004). During menopause, women face various physiological, psychological and biochemical changes. The adverse effects of menopause are attributed to a decrease in the estrogen level, which leads to alternations in body mass index, insulin levels and also to increase the risk of hypertension, cardiovascular diseases, osteoporosis, diabetes mellitus, cancer and other degenerative changes in postmenopausal females (Burger et al., 2002). Osteoporosis is the term used for diseases that cause a reduction in the mass of bone per unit volume and it is one of the dreaded afflictions of aging. There is a close relationship between estrogen deprivation and its development (Ashuma et al., 2005). Despite its seemingly static appearance, bone is a remarkably labile tissue and bone turnover is a dynamic process which increases in postmenopausal period as a consequence of estrogen deficiency (Uemura et al., 2000). Bone loss occurs when the balance between formation and resorption is upset, and resorption is excessive resulting in a negative remodeling balance (Dogan and Posaci, 2002). Biochemical markers of bone turnover have been shown to provide valuable information for the diagnosis and monitoring of metabolic bone disease (Delmas et al., 2000). The rate of formation or degradation of the bone matrix can be assessed by measuring the enzymetic activity related to the bone forming or resorbing cells. Bone matrix components are released into the circulation, either by the osteoblasts or by the osteoclasts (Ashuma et al., 2005). Numerous studies have observed increased bone resorption in postmenopausal women and many markers of bone resorption and formation have been identified (Garcia-Perez et al., 2004; Harimarayan, 2005; Suresh and Naidu, 2006). Tartrate-resistant acid phosphatase 5b (TRACP 5b; EC 3.1.3.2) was discovered from human leukocytes and named as type 5 acid phosphatase according to the electrophoretic mobility in native polyacrylamide gel (Li et al., 1973). It is a unique bone resorption marker, since it is the only marker released from resorbing osteoclasts into the circulation (Janckila et al., 2001). The occurrence of Osteoporosis in postmenopausal women is very common problem but there are very few Iraqi studies regarding the prevalence of osteoporosis in postmenopausal women and also regarding the biochemical markers which indicate bone turnover. Menopause also affects calcium status (Nordin et al., 2004). Calcium ion is an essential component of skeleton, soft tissues and extra- cellular fluid. The skeleton contains $99 \%$ of bodies' calcium. Soft tissue and extra- cellular fluid contain about $1 \%$ of the body s calcium. There are growing 
evidences for the importance of nutrition in the maintenance of bones and joints health (Qureshi et al., 2010). Nutrition imbalance with endocrine abnormalities may be involved in osteoporosis (Sheweita and Khoshal, 2007). Adverse changes in serum calcium, ACP and TRACP activity, total protein and albumin due to estrogen deficiency have been implicated in the increased incidence of osteoporosis in postmenopausal women (Recker et al., 1998). Despite the doubling of the incidence of gout among women over the past twenty years (Arromdee et al., 2002) and the substantial prevalence particularly in the aging female population (Kramer and Curhan, 2002), little is known about the risk factors for gout and hyperuricaemia specifically among women. Elevated circulating serum uric acid concentrations may be linked to an increased risk of coronary heart disease (CHD) (Simon et al., 2006).

The aim of this study was to evaluate the effect of menopause on TRACP activity as one of bone resorption markers, and the status of calcium and uric acid; to study the possibility of using these biochemical parameters to early diagnose of osteoporotic changes in the normal menopausal women by easy colorimetric methods to avoid the risk of osteoporosis, fractures and coronary heart diseases.

\section{Subjects}

\section{MATERIAL AND METHODS}

This study was carried out at the Chemistry Department, College of Education for Girls/ Mosul University. The study was conducted on 50 apparently healthy females selected from the general populations, out of which 25 were of premenopausal age, (mean $=47.18 \pm 4.10$ years) with regular menstruation, and 25 were of postmenopausal age (mean $=58.58 \pm 4.51$ years) with natural menopause, permanent cessation of the menstrual cycle for more than one year. A narrow range of age group was taken to reduce the effect of aging as it is a factor affecting the bones and the measured parameters. All the selected subjects were healthy and were not suffering from any diseases like hypertension, diabetes mellitus, rheumatoid arthritis and malignancy. Also none of the subjects was on any medical treatment. The height and weight of subjects were measured and used in calculating Body Mass Index (BMI Kg/m²).

\section{Samples collection}

For assessment of various parameters, $(5 \mathrm{ml})$ of venous blood samples were collected from each subject, without tourniquet, under aseptic conditions and after overnight fasting. Samples were centrifuged at $(2000 \mathrm{xg})$. The obtained sera samples were estimated directly for enzyme activities or frozen at $-20 \mathrm{C}$ for subsequent analysis. Hemolyzed samples were discarded.

\section{Methods}

The activity of total acid phosphatase (ACP) and tartarate-resistant acid phosphatase (TRACP 5b) were determined using 4- nitrophenol phosphate (4-NPP) as substrate (Lau et al., 1987; Janckila et al., 2001). Total protein (TP) concentration was determined by Biuret method (Burtis and Ashwood, 1986) using kit manufactured by Biolabo (France). Albumin (alb) concentration was determined by dye-binding method (Doumas et al., 1971) using kit 
manufactured by Biolabo. The concentration of the globulin was determined by using the following equation:

$$
\mathrm{C}_{\mathrm{glob}}(\mathrm{g} / \mathrm{dl})=\mathrm{C}_{\mathrm{TP}}-\mathrm{C}_{\mathrm{alb}}
$$

Calcium concentration was determined by CPC method (ortho-Cresol Phthalein Complexone method) (Connerty and Briggs, 1966) using Biolabo kit (France).

Corrected total calcium $(\mathrm{mmol} / \mathrm{L})=$ measured calcium $(\mathrm{mmol} / \mathrm{L})+0.02(40$-measured albumin $\mathrm{g} / \mathrm{L})$.

Uric acid concentration was determined according to uricase method (Artiss and Entwistl, 1981) by using Biolabo kit (France).

\section{Statistical analysis}

Statistical analysis was carried out using Student's paired $t$-test. The data were expressed as Mean \pm SD and (P) values $<0.05$ were taken as significant.

\section{RESULTS AND DISCUSSION}

Table (1) shows the Mean \pm SD value of age, body mass index, total protein, albumin, and globulin. The results of this study showed that the postmenopausal women have a nonsignificant decrease $(\mathrm{P}>0.05)$ in $\mathrm{BMI}$ as compared to premenopausal women. Total protein was significantly increased $(\mathrm{P}<0.01)$ in post menopausal women when compared to premenopausal women. There was no significant difference $(\mathrm{P}>0.05)$ in the albumin and globulin values of both groups.

Table 1: Mean value of age, body mass index (BMI), total proteins, albumin, globulin in premenopausal and postmenopausal women

\begin{tabular}{|l|l|l|l|}
\hline Variables & $\begin{array}{l}\text { Pre-menopausal } \\
\text { Women (n=25) }\end{array}$ & $\begin{array}{l}\text { Post-menopausal } \\
\text { Women (n=25) }\end{array}$ & (P) value \\
\hline Age $($ years) & $47.18 \pm 4.1$ & $58.58 \pm 4.51$ & \\
\hline BMI $\left(\mathrm{kg} / \mathrm{m}^{2}\right)$ & $33.02 \pm 4.37$ & $31.95 \pm 4.6$ & 0.36 \\
\hline Total protein $(\mathrm{g} / \mathrm{dl})$ & $6.75 \pm 0.40$ & $7.43 \pm 0.42$ & $0.001^{*}$ \\
\hline Albumin $(\mathrm{g} / \mathrm{dl})$ & $3.91 \pm 0.57$ & $4.23 \pm 0.35$ & 0.06 \\
\hline Globulin $(\mathrm{g} / \mathrm{dl})$ & $2.83 \pm 0.55$ & $3.08 \pm 0.47$ & 0.32 \\
\hline
\end{tabular}

- $\quad$ Statistically significant $(\mathrm{P} \leq 0.001)$

Menopause is associated with numerous physiological and biochemical changes. Results from our study have shown that body mass index (BMI) has a non significant decrease. According to World Health Organization (WHO) criteria (Qureshi et al., 2010), pre-menopausal women were obese $\left(B M I>30 \mathrm{~kg} / \mathrm{m}^{2}\right)$ and also were postmenopausal women with little decrease. This was attributed to number of years since menopause and advancing age, since aging is often associated with loss of height, weight and development of stooped posture (Usoro et al., 2007). Low BMI has been known to be a risk factor for osteoporosis.

Overall body protein status is usually assessed through the levels of total protein and albumin in serum. The results of our study showed that the total protein was elevated in 
postmenopausal women as compared to premenopausal women. However, serum total protein was relatively higher in menopausel women which confirms previous findings (Javed et al., 2000, Ashuma et al., 2005 and Kumari et al., 2010), and it was attributed to aging and metabolic processes affected by menopause. The elevated total serum protein levels may also indicate dehydration, high protein and high calorie diet, liver/biliary dysfunction ... etc. (Kumari et al., 2010). Albumin concentration showed a non significant increase in postmenopausal women as compared to premenopausal women and it is well known that albumin concentration contributes significantly in alternation of serum total protein level (Javed et al., 2000).

Results in table (2) showed the presence of a significant increase in the activity of acid phosphatase (ACP) and tartarate resistant acid phosphatase (TRACP 5b) in postmenopausal women as compared to premenopausal women. The mean level of total calcium was significantly increased in postmenopausal women compared to premenopausal women. High significant increase was observed in the mean level of uric acid of postmenopausal women compared to premenopausal women.

Table 2: Mean value of ACP and TRACP activity, total calcium, corrected calcium and uric acid levels in premenopausal and postmenopausal women.

\begin{tabular}{|l|l|l|l|}
\hline \multicolumn{1}{|c|}{ Variables } & $\begin{array}{c}\text { Pre-menopausal } \\
\text { Women }(\mathbf{n}=25)\end{array}$ & \multicolumn{1}{|c|}{$\begin{array}{c}\text { Post-menopausal } \\
\text { Women }(\mathbf{n}=25)\end{array}$} & \multicolumn{1}{|c|}{$(\mathbf{P})$ value } \\
\hline ACP (IU/L) & $5.98 \pm 3.88$ & $9.62 \pm 3.8$ & $0.032^{*}$ \\
\hline TRACP (IU/L) & $2.91 \pm 1.72$ & $5.11 \pm 2.06$ & $0.008^{* *}$ \\
\hline Total Calcium (mmol/l) & $2.19 \pm 0.31$ & $2.64 \pm 0.54$ & $0.022^{*}$ \\
\hline Corrected calcium (mmol/l) & $2.28 \pm 0.48$ & $2.59 \pm 0.53$ & 0.09 \\
\hline Uric acid (mg/dl) & $3.73 \pm 0.84$ & $5.47 \pm 1.40$ & $0.0001^{* *}$ \\
\hline
\end{tabular}

*Statistically significant $(\mathrm{P}<0.05),{ }^{* *}$ Statistically significant $(\mathrm{P}<0.01)$

Biochemical parameters can give an idea about the rates of bone formation and resorption. The results revealed a significant increase in ACP and TRACP 5b activities in postmenopausal women when compared to premenopausal women and this is in accordance with many studies (Dogan and Prosaci, 2002; Rico et al., 2002; Suresh and Naidu, 2006) that in early menopausal women there is a high acid phosphatase activity as a result of the inhibitory effects of estrogen on bone turnover rate which is dependent on age. It is well known that estrogen deficiency induces the synthesis of cytokines by the osteoblasts, monocytes and T-cells and thereby stimulates bone resorption by increasing osteoclastic activity (Esbrit, 2001). Estrogen exerted also a major effect on bone remodeling by inhibiting interleukin (IL)-6 production that reduces bone resorption and also controls the timing of osteoclast apoptosis (Garneo and Delmas, 2004). This upsets the normal balance between bone resorption and bone synthesis. The increase in osteoclast activity is accompanied by an increase in the synthesis and secretion of TRACP 5b (Halleen et al., 2000). In general, women lose about $1-5 \%$ of their bone density per year during and after menopause (Kumari et al., 2010), that contributes to the development of osteoporosis. Estrogen inhibits bone resorption and this may justify the influence of this hormone on osteoclastic activity. So, early detection of bone loss by measuring TRACP 5b activity helps 
to confirm the diagnosis of osteoporosis and assesses the future risk of osteoporotic fractures.

The results in Table (2) showed a significant increase in total calcium and this agrees with other studies (Ashuma et al., 2005; Suresh and Naidu, 2006; Usoro et al., 2007). Calcium ion is an essential structural component of the skeleton. Extracellular calcium ion concentration is determined by the interaction of calcium absorption from the intestine, renal excretion of calcium and bone uptake and release of calcium (Sheweita et al., 2007). In postmenopausal women, estrogen deficiency may induce calcium loss by indirect effects on extra skeletal calcium homeostasis. Parathyroid hormone causes bone resorption and helps to maintain blood calcium levels. Levels of serum parathyroid hormone increased progressively with age in women due to estrogen deficiency, and so correlate significantly with the increase in bone turnover (Qureshi et al., 2010). Intestinal calcium absorption also, decreases in postmenopausal women (Nordin et al., 2004). All these factors are leading to increase circulating levels of calcium ion and that was obvious in the results of this study. A recent study found an independent association between the higher baseline serum calcium levels and the higher rate of cardiovascular events (Slinin et al., 2011). Because calcium is predominantly transported bound to serum proteins, total calcium levels are greatly influenced by protein concentration especially albumin (Sava et al., 2005).

The quality of life of women after menopause is one of the key health issues today (Agrawal et al., 2009). There are growing evidences for the importance of nutrition in the maintenance of bones and joints health. Diet has been proven to be an independent risk factor for the development of osteoporosis. High protein diet (non-vegetarian diet particularly) leads to excessive acid formation which may contribute to dissolution of bones as the body tries to buffer the extra acid. Acidosis may also increase osteoclastic function directly (Ashuma et al., 2005). Studies have shown that postmenpausal women with high total protein intake and high animal/vegetable protein ratio have a higher incidence of fractures (Sellmeyer and stone, 2001). High animal protein intake also induces high uric acid level.

Results in Table (2) showed a highly significant increase in uric acid level in postmenopausal women as compared with premenopausal women. This agrees with the study of (Hak and Choi, 2008) who indicat that menopause was associated with a higher serum uric acid level. The increases in serum uric acid in postmenopausal women may result from the changes in metabolism as a consequence of the menopause (Callums et al., 1998). Estrogen may help the kidney to excrete uric acid, so after menopause, a women's uric acid level begins to increase. It usually takes several years for the uric acid level to reach the point where crystals can form. Elevated circulating serum uric acid level may be linked with an increased risk of coronary heart disease (CHD) (Simon et al., 2006).

In conclusion, this study shows an increase in the activity of both, ACP and TRACP $5 \mathrm{~b}$, and an increase in total calcium level in postmenopausal women which indicates that postmenopausal women are more prone to osteoporosis and fractures. Also the study indicates that menopause is associated with higher serum uric acid level which may be linked with an increased risk of coronary heart diseases. 


\section{REFERENCES}

Agrawal, S.; Jain, A.; Mahajan, D.; Raghunandan, C. (2009). Correlation of bone mineral density with biochemical markers in postmenopausal women. Indian J. Clin. Biochem., 24(3), 262-265.

Arromdee, E.; Michel, C.J.; Crowson, C.S.; Ofallon, W.M.; Gbriel, S.E. (2002). Epidemiology of gout: is the incidence rising?. J. Reheumatol., 29, 2403-2406.

Artiss, J.D.; Entwistl, W.M. (1981). The application of sensitive uricase-peroxidase coupled reaction to a centrifugal test analyzer for the determination of uric acid. Clin. Chem. Acta., 116, 301-309.

Ashuma, S.; Shashi, S.; Sachdeva, S. (2005). Biochemical markers of bone turnover; diagnostic and therapeutic principles. Osteoporosis, 332, 305-311.

Burger, E.F.; Kustin, A.A.; Baron D.C. (2002). Endocinology and metabolism. Ann. Int. Med., 252, 872-942.

Burtis, C.A.; Ashwood, E.R. (1986). "Tietz Text Book of Clinical Chemistry". W. B. Saunders Co. Philadelphia, 579 p.

Callums, S.; Christopher, W.; Stevenson, J. (1998). The effect of menopause on serum uric acid levels in non-obese healthy women. Metabolism., 47(4), 435-438.

Connerty, H.V.; Briggs, A.R. (1966). Determination of serum calcium by means of orthocresophthalein complexon. Am. J .Clin. Pathol., 45, 290-6.

Delmas, P.; Eastell, R.; Garnero, P.; Seibel, M.; Stepan, J. (2000). The use of biochemical markers of bone turnover in osteoporosis. Osteoporos Int. Suppl., 6, 2-17.

Dogan, E.; Posaci, C. (2002). Monitoring hormone replacement therapy by biochemical markers of bone metabolism in menopausal women. Post Graduate Med. J., 78, 727-731.

Doumas, B.T.; Watson, W.A.; Biggs, H.G. (1971). Albumin standard and the measurement of serum albumin with bromogresol green. Clin. Chem. Acta, 31, 87-96.

Esbrit, P. (2001). Hypercacemia of malignancy: New insights into an old syndrome. Clin. Lab., 47, 67-71.

Garcia-Perez, M.A.; Moreno-Mercer, M.A.; Tarin, J.J.; Cano, A. (2004). Bone turnover markers and PTH levels in surgical versus natural menopause. Calcif. Tissue Int., 74, 143-149.

Garneo, P.; Delmas, P. (2004). Bone turnover markers. In:" Encyclopedia of Endocrine disease". Eds Martin L. California. Elsevier Inc. pp. 401-13.

Hak, A.L.; Choi, H. K. (2008). Menopause, postmenopausal hormone use and serum uric acid levels in US women. The Third National Health and Nutrition Examination Survey. Arithritis Research and Therapy, 10 (5), 116-22.

Halleen, J.M.; Alatalo, S.I.; Suominen, H. (2000). Tartarate-resistant acid phosphatase 5b: a novel serum marker of bone resorption. J. Bone Minor Res., 15, 1337-45.

Harimarayan, C.V. (2005). Prevalence of vitamin insufficiency in postmenopausal south Indian women. Osteoporosis Int., 16, 397-402.

Janckila, A.J.; Takahashi, K.; Sun, S.Z.; Yam, L.T. (2001). Naphthol-ASBI phosphate as a preffered substrate for TRAC 5b isoform. J. Bone Minor Res., 16(4), 788-93

Javed, M.T.; Almas, K.; Cheema, S.T.; Zahoor, T. (2000). A study on serum proteins in diabetic pregnant and menopausal women of two socio-economic statuses. Med. J. Islamic Academy Sci., 13(4), 155-160. 
Kramer, H.M.; Curhan, G. (2002). The association between gout and nephrolithiasis: The National Health and Nutrition Examination Survey III, 1988-1994. Am. J. Kidney Dis., 40, 37-42.

Kumari, K.N.; Rosario, S.B.; Gowda, K.M. (2010). Altered liver function and the status of calcium in postmenopausal women in and around mangalore. Al Ameen J. Med. Sci., 3(2), 115-119.

Lau, K.H.; Onishi, T.; Wergedal, J.E.; Singer, F.R.; Baylink, D.J. (1987). Characterization and assay of tartarate-resistant acid phosphatase activity in serum: potential use to assess bone resorption. Clin. Chem., 33(4), 458-62.

Li, C.Y; Chuda, R.A.; Lam, W.K.; Yam, L.T. (1973). Acid phosphatases in human plasma. J. Lab. Clin. Med., 82(3), 446-60.

Nordin, B.C.; Need, A.G.; Morris, H.A.; Oloughlin, P.D.; Horowitz, M. (2004). Effect of age on calcium absorption in postmenopausal women. Am. J. Clin. Nut., 80, 9981002.

Padubidri, V.G.; Daftary, S.N. (2004). "Bourne Shaw's Text Book of Gynaecology". 13th ed. Elsevier, New Delhi. pp. 56-58.

Qureshi, H.J.; Hussain, G.; Jafary, Z.A.; Bashir, M.U.; Latif, N.; Riaz, Z. (2010). Calcium status in premenopausal and postmenopausal women. J. Ayub Med. Coll. Abbottabad, 22(2), 143-145

Recker, R.R.; Heaney, R.P.; Saville, P.D. (1998). Menopausal changes in bone remodeling. J. Lab. Clin. Med., 92, 964-970.

Rico, H.; Arribas, I.; Villa, L.; Casanovo, F.; Hernandz, E.; Cortes-Prieto, J. (2002). Can a determination of tartarate-resistant acid phosphatase predict postmenopausal loss of bone mass?. European J. Clin. Invest., 32(4), 274-278.

Sava, L.; Sandhya, P.; Umesh, M. (2005). Serum calcium measurement: Total versus free (ionized) calcium. Indian J. Clin. Biochem., 20(2), 158-161.

Sellmeyer, D.E.; Stone, K.L. (2001). High ratio of dietary animal-vegetable protein increases the rate of bone loss and risk of fracture in postmenopausal women. Am. J. Cli. Nutr., 73, 118-22.

Sheweita, S.; Khoshal, K. ( 2007). Calcium metabolism and oxidative stress in bone fractures. Role of antioxidants. Curr. Durg. Metab., 8, 519-25.

Simon, J.A.; Lin, F.; Vittinghoff, E.; Bittner, V. (2006). The relation of postmenopausal hormone therapy to serum uric acid and the risk of coronary heart disease events: the heart and estrogen-progestin replacement study (HERS). Ann. Epidemiol., 16, 138-145.

Slinin, Y.; Blackwell, T.; Ishani, A.; Cumming, S.; Ensrud, K. (2011). Serum calcium, phosphorus and cardiovascular events in postmenopausal women. Int. J. Cardiol., 149(3), 335-40.

Suresh, M.; Naidu, D.M. (2006). Interference of years since menopause on bone mineral metabolism in south Indian women. Indian J. Med. Sci., 60, 193-195.

Uemura, H.; Irahara, M.; Yoneda, N.; Yasui, T.; Genjida, K. (2000). Close correlation between estrogen treatment and renal phosphate reabsorption capacity. J. Clin. Endocrinol., 85, 1215-1219.

Usoro, C.A.; Onyeukwu, C.U.; Nsonwu, A. C. (2007). Biochemical bone turnover markers in postmenopausal women in Calabar Municipality. Asian J. Biochem., 2(2), 130135. 